\title{
Impact of Apple Rust Mite (Acari: Eriophyiidae) Feeding on Apple Leaf Gas Exchange and Leaf Color Associated with Changes in Leaf Tissue
}

\author{
FREDY SPIESER, ${ }^{1}$ BENNO GRAF, ${ }^{1}$ PAUL WALTHER,${ }^{2}$ AND JOSEF NOESBERGER ${ }^{3}$
}

\begin{abstract}
Environ. Entomol. 27 (5): 1149-1156 (1998)
ABSTRACr The impact of the apple rust mite, Aculus schlechtendali (Nalepa), on net $\mathrm{CO}_{2}$ exchange, transpiration rate, and leaf color of field-grown Jonagold and Golden Delicious apples was investigated. Apple rust mite feeding causes leaf browning. Changes in leaf color were measured to assess the cumulative leaf damage. Significant negative relationships were found between cumulative leaf damage and single-leaf net $\mathrm{CO}_{2}$ exchange as well as transpiration rate. The same trends were observed on both varieties, but the effect of apple rust mite feeding was more severe on Jonagold than on Golden Delicious. Leaf tissue injury was analyzed by cryoscanning electron microscopy and light microscopy. The pictures show that apple rust mites penetrate epidermal cells with their stylets, causing multiple puncture wounds. On heavily infested leaves, apple rust mite feeding causes desiccation of the epidermis and the spongy parenchyma. The resulting malfunction of the stomata and problems in gas exchange within the spongy parenchyma are likely to be the main reason for the reduction of gas exchange.
\end{abstract}

KEY WORDS Aculus schlechtendali, apple, photosynthesis, transpiration, leaf injury, Eriophyiidae

The effects of the apple rust mite, Aculus schlechtendali (Nalepa), feeding on plant ecophysiology are not well understood. Another acarine apple system that is more intensively studied is the spider mite (Tetranychidae) apple complex where various studies have been done on the impact of spider mite feeding on ecophysiological processes such as gas exchange (Hall and Ferree 1975, Campbell et al. 1990a, Mobley and Marini 1990, Francesconi et al. 1996, Lakso et al. 1996). However, in contrast to spider mites which are mesophyll feeders, rust mites (Eriophyiidae) can penetrate only epidermal cells with their small mouthparts (McCoy and Albrigo 1975, McCoy 1976, Easterbrook and Fuller 1986, Andersen and Mizell 1987, Royalty and Peering 1988). Therefore, tissue injury and plant reactions caused by rust mites and spider mites are expected to be different.

Rust mites can be found on a wide range of host plants such as apple, pear, tomato, peach, plum, and citrus. Although the species are different, the symptoms on the host plants are quite similar. Most rust mite studies investigated the interactions between citrus and the citrus rust mite (McCoy and Albrigo 1975; McCoy 1976; Achor et al. 1991; Yang et al. 1994; Yang et al. 1995a, b). Some studies focused on the impact of tomato russet mite Aculops lycopersici (Massee) on tomatoes (Zalom et al. 1986; Royalty and Peering 1988,

\footnotetext{
'Swiss Federal Research Station for Fruit-Growing, Viticulture and Horticulture, CH-8820 Wädenswil, Switzerland

${ }^{2}$ Laboratory for Electron Microscopy 1, ETH Zentrum, CH-8092 Zürich, Switzerland.

${ }^{3}$ Institute of Plant Sciences, ETH Zentrum, CH-8092 Zürich, Switzerland.
}

1989; Stout et al. 1994). However, not much work has been done on the apple rust mite apple system.

Apple rust mite is a leaf vagrant eriophyoid and feeds on flowers, fruits and, leaves of apple. It is a typical epidermis feeder with stylets of $\approx 13 \mu \mathrm{m}$ that penetrate just the outermost cell layer. Apple rust mite causes various symptoms on apple: leaves roll up longitudinally and become rusty brown on the lower side (Jeppson et al. 1975; Höhn and Höpli 1990). Another damage is fruit russeting caused by mite feeding on flower receptacles and fruitlets, resulting in epidermal cell damage (Easterbrook and Fuller 1986).

Since the late 1960s, the pest status of apple rust mite has increased in many countries. This is probably because of a combination of factors including an increased use of nonacaricidal fungicides, intensive management in modern apple orchards, and the use of pesticides toxic to predators (Easterbrook 1996). A thorough understanding of apple rust mite-apple tree interactions is a prerequisite for sustainable management strategies in commercial orchards. In this study the mechanisms of apple rust mite feeding and its effect on gas exchange and leaf injury were investigated.

\section{Materials and Methods}

Trees. The experiments were carried out with plants grown under field conditions and artificially infested with apple rust mites. The experimental plot was situated on the premises of the Swiss Federal Research Station Wädenswil. In October 1994, 300 one-year-old apple trees-150 Jonagold and 150 Golden Deli- 
Table 1. Sealing key between $a^{*}$ values (green-red axis) and damage units

\begin{tabular}{|c|c|c|c|c|c|c|c|c|c|c|c|}
\hline \multirow[b]{2}{*}{$\begin{array}{l}\text { Damage unit } \\
a^{*} \text { values }\end{array}$} & \multirow[b]{2}{*}{$\begin{array}{c}0 \\
-14.0\end{array}$} & \multicolumn{6}{|c|}{$\begin{array}{r}\text { Healthy leaf } \\
\text { Green }\end{array}$} & \multicolumn{4}{|c|}{$\begin{array}{l}\text { Damaged leaf } \\
\text { Brown }\end{array}$} \\
\hline & & $\begin{array}{c}1 \\
-12.8\end{array}$ & $\begin{array}{c}2 \\
-11.6\end{array}$ & $\begin{array}{c}3 \\
-10.4\end{array}$ & $\begin{array}{c}4 \\
-9.2\end{array}$ & $\begin{array}{c}5 \\
-8.0\end{array}$ & $\begin{array}{c}6 \\
-6.8\end{array}$ & $\begin{array}{c}7 \\
-5.6\end{array}$ & $\begin{array}{c}8 \\
-4.4\end{array}$ & $\begin{array}{c}9 \\
-3.2\end{array}$ & $\begin{array}{c}10 \\
-2.0\end{array}$ \\
\hline
\end{tabular}

cious-on rootstock $\mathrm{M} 9$ were planted in 2 rows in buried 24-liter pots. Three plots containing 15 trees within each row were chosen as control and were kept free of mites. In summer, the trees were irrigated by drip irrigation to ensure water was not a limiting factor for growth. A slow-release fertilizer (Osmocot, 13\% nitrogen) at a rate of 10-12 g per tree was applied in spring 1995 and 1996. The number of flowers and fruits per tree were equalized manually each spring to provide more homogeneous apple trees.

Overview of Measurements. On single leaves, the rust mite densities were counted, the changes in leaf color as indicator for damage, and the physiological parameters net $\mathrm{CO}_{2}$ exchange and transpiration were measured. All these parameters were recorded on the same leaf. In addition, cryoscanning electron and brightfield light microscopy were used to investigate changes in leaf tissue.

Mite Management and Sampling. The objective of the mite management treatments was to produce a population as high as possible on infested trees (some thousands of mites per leaf) and a population on noninfested trees (as low as possible) to measure differences in gas exchange, leaf color, and leaf tissue. Before bud break in spring 1995, apple rust mite populations were established on all trees by means of infested shoots from a neighboring orchard. One randomly chosen plot per block was treated with brompropylate $250 \mathrm{~g} /$ liter EC on 16 May and 9 July 1996 to obtain noninfested trees. The plant protection spray program contained 9 applications of fungicides (copper, dithianon, captan, pyrifenox, bupirimate) and 3 applications of insecticides (pirimicarb, fenoxycarb, tebufenozide) between May and July 1996.

The apple rust mite populations were sampled 8 times on Jonagold and three times on Golden Delicious between 6 June and 19 July 1996. On every sampling day, 1 leaf per tree from $\approx 20$ infested and 10 noninfested trees were chosen. The 5 th leaf from the top of a growing shoot was selected to standardize the sample. Apple rust mite populations were estimated on detached leaves using a stereo microscope at $40 \times$ magnification. A grid was placed on the lower side of the leaf and the apple rust mites were counted in every square $\left(16-\mathrm{mm}^{2}\right)$ in a row perpendicular from the midrib to the edge of the leaf, at the same place where the gas exchange rate was measured. Six to 10 squares per leaf were sampled depending on the width of the leaf. The average of all counts was used for further calculations.

Indicator of Leaf Damage. One visible symptom of apple rust mite infestations is a rusty brown color on the lower surface of the leaf (Jeppson et al. 1975; Höhn and Höpli 1990). This brownness is caused by cell damage and oxidation processes within the cell (Elstner 1990). The color of the lower leaf surface was measured 8 times on Jonagold and 3 times on Golden Delicious between 14 June and 21 July 1996 using a Minolta chromameter (CR-300, $\mathrm{D}_{65}$ ). The colors are described in the $\mathrm{L}^{*} \mathrm{a}^{*} \mathrm{~b}^{*}$ color system. $\mathrm{L}^{*}$ is the lightness variable, and $a^{*}$ and $b^{*}$ are the chromaticity co-ordinates and describe the green-red and the blueyellow axes, respectively. Color measurements were repeated 6 times on the same leaf area where the gas exchange parameters and the rust mite densities were recorded. The average of the 6 a*values (green-red) was used as an indicator of leaf damage. For a better understanding, the $a^{*}$ values were scaled in damage units from 0 (no damage) to 10 (severe damage). The scaling key between a*values and damageunits is shown in Table 1.

Gas Exchange Measurements. Apple rust mites might change leaf tissue by feeding on it. Therefore, an impact on gas exchange can be expected. For single-leaf gas exchange measurements, a portable LCA-4 infrared gas analyzer system with a portable light unit (Analytical Development, Hoddesdon, England) was used. The 5th leaf from the top of a growing shoot exposed to the sun was selected to measure gas exchange. The leaves were detached for measurement and gas exchange was recorded within $<2$ min. For standardization, all measurements were made between 1000 and 1200 hours. During measurement, the leaf was exposed to saturated and constant light from an artificial light source, which allowed the measurements to be taken in the shade and hence to prevent strong temperature fluctuations within the leaf cuvette. After gas exchange measurement, the leaf was stored in a thermal isolated box for recording leaf color and assessing apple rust mite density. The gas exchange measurements were carried out 7 times on Jonagold and 3 times on Golden Delicious between 14 June and 19 July 1996. On each sampling day, 14-32 infested and 8-11 noninfested leaves were chosen.

An additional experiment was carried out to check whether gas exchange measurements were affected by leaf detachment. The selection of the leaves and the measurement method were similar to those mentioned above. On August 18 and on September 18, the measurements were carried out in the field on 16 and 15 noninfested Jonagold trees, respectively. The gas exchange was measured on the nondetached leaf first. After taking the leaf out of the cuvette and waiting for $5 \mathrm{~min}$ to prevent a cuvette influence, the measurement was repeated on the detached leaves. Neither net $\mathrm{CO}_{2}$ exchange rate nor transpiration rate showed any significant differences between detached and nondetached leaves $(t=0.306, \mathrm{df}=30, P<0.05)$. 
We also tested whether the acaricide (brompropylate) used to control apple rust mite density influences gas exchange parameters. The selection of the leaves and the measurement method were similar to those mentioned above. In July 1996, measurements were carried out in the field on 35 noninfested Jonagold trees. On July 12, gas exchange was recorded the 1st time. Afterward on the same day, 17 trees were treated with brompropylate. On July 16, the gas exchange measurements were repeated on the same leaves. We measured no significant difference in gas exchange parameters between treated and untreated leaves $(F=1.0 ; \mathrm{df}=1,33 ; P<0.05)$.

Cryoscanning Electron Microscopy. It is likely that apple rust mites leave behind traces of their feeding activity on leaf surfaces. Therefore, mechanical damage was analyzed by means of cryoscanning electron and light microscopy. For electron microscopy, leaf samples were punched out with an ophtalmological punch and frozen in liquid nitrogen. Frozen samples were mounted on a GATAN cryoholder and cryosputter-coated with $7 \mathrm{~nm}$ of platinum at a temperature of $140 \mathrm{~K}$ in a MED 020 (Bal-Tec, Liechtenstein). The samples were cryotransferred in liquid nitrogen to a Hitachi S-900 in-lens field emission scanning electron microscope. Images of the frozen hydrated samples were recorded digitally at a temperature of $140^{\circ} \mathrm{K}$ and an accelerating voltage of $10 \mathrm{kV}$ using the backscattered electron signal as described by Walther and Müller (1997).

Brightfield Light Microscopy. Leaves were fixed chemically overnight with $3 \%$ glutaraldehyde in cacodylate buffer and for $2 \mathrm{~h}$ in $2 \%$ osmium tetroxide in cacodylate buffer. Samples were then dehydrated in a graded series of ethanol and embedded stepwise in epon-araldyte (Fluka, Buchs, Switzerland). Sections of $1 \mu \mathrm{m}$ were cut with a Reichert ultracut E (Leica) and a Histo diamond knife (Diatome, Biel, Switzerland). Sections were stained with methylene blue.

\section{Results}

Population Development. The development of populations on the 2 apple varieties was similar (Fig. 1). A small initial population of apple rust mites occurred on the untreated trees at the beginning of June 1996 ( $<1$ mite per $16 \mathrm{~mm}^{2}$ leaf area; <400 mites per leaf). On mid-June, the population reached a level of $\approx 10$ apple rust mites per $16 \mathrm{~mm}^{2}$ (i.e., $4,000-5,000$ mites per leaf) within only a few days. Until mid-July the population was at a very high but more or less constant level. On mid-July $\approx 2$ wk after the completion of shoot growth, the population decreased quickly. On trees that were treated with brompropylate, some apple rust mites were found at the beginning of June. However, no outbreak was observed in mid-June and the population remained at a low level.

Browning of Leaves. Leaves that were infested with apple rust mites turn brownish, whereas noninfested leaves hardly changed color (Fig. 2). The color changes on infested leaves occurred simultaneously with the apple rust mite population increase-light

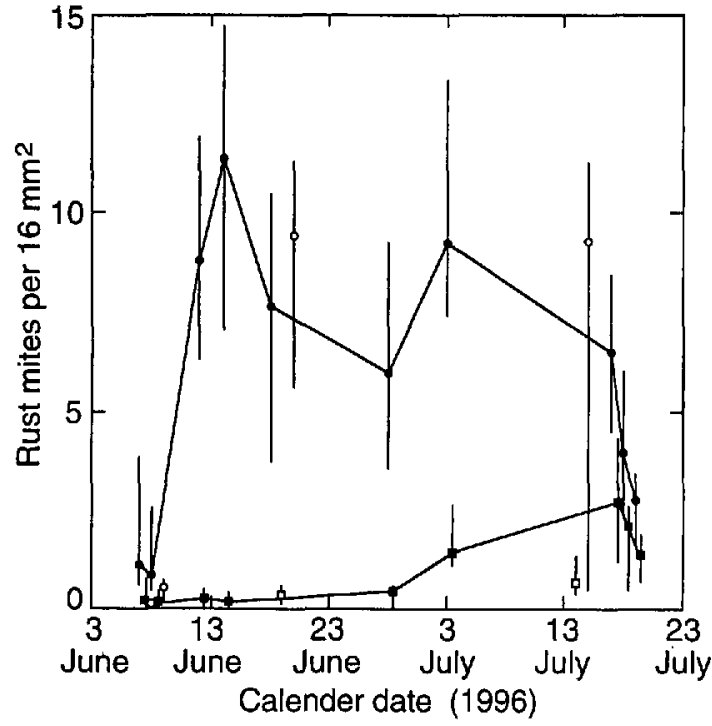

Fig. 1. Population development of apple rust mite on the 2 apple varieties, Jonagold (full symbols) and Colden Delicious (open symbols): squares show samples of trees that were treated with an acaricide; circles show samples of untreated trees. Medians with interquartile ranges were used because this statistic is not as sensitive to extreme values and therefore describes more robust center values of high variability parameters than means.

brown turned to intensive brown from early June to early July. Unlike the apple rust mite populations, the brownness did not disappear at the end of July.

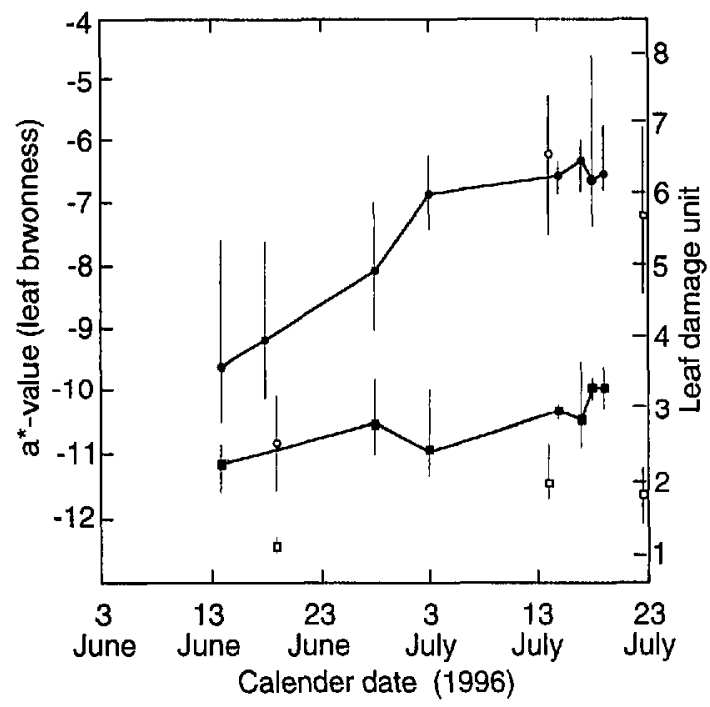

Fig. 2. Development of $a^{*}$-value (left scale) and leaf damage (right scale) on the 2 apple varieties, Jonagold (full symbols) and Golden Delicious (open symbols): squares show samples of trees that were treated with an acaricide; circles show samples of untreated trees. Medians with interquartile ranges were used because this statistic is not as sensitive to extreme values and therefore describes more robust center values of high variability parameters than means. 


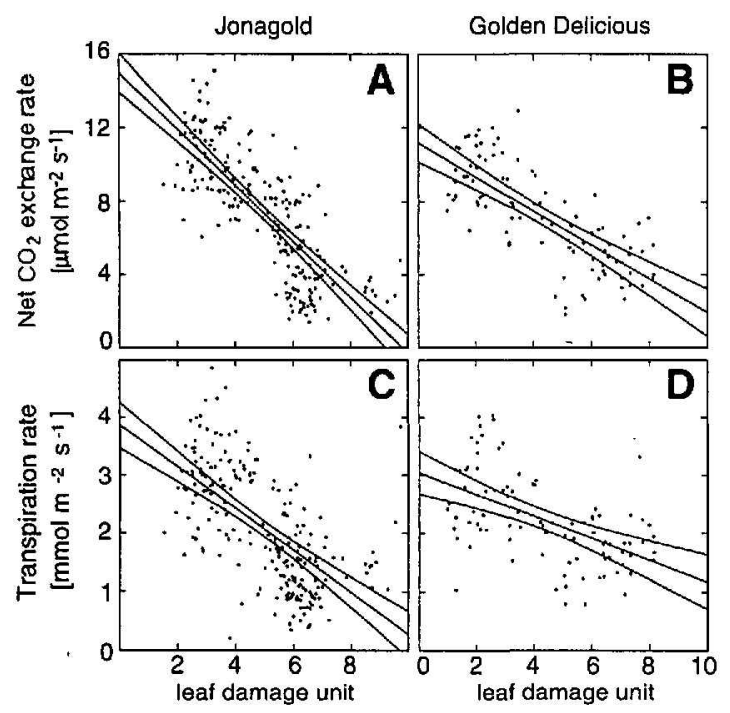

Fig. 3. Effect of leaf damage caused by apple nust mites on net $\mathrm{CO}_{2}$ exchange $(A$ and $B$ ) and transpiration rate $(C$ and D) on Jonagold $(A ; C)$ and Golden Delicious $(B ; D)$. The figures show $95 \% \mathrm{CI}$ on the linear regression lines. The equations for the linear regression are as follows: (A) $y=$ $14.998-1.531 \mathrm{x}, n=219, r^{2}=0.63, P<0.001$; (B) y $=3.861$ $-0.359 \mathrm{x}, n=219, r^{2}=0.39, P<0.001 ;(\mathrm{C}) \mathrm{y}=11.174-$ $0.924 \mathrm{x}, n=94 ; r^{2}=0.56, P<0.001$; (D) $\mathrm{y}=3.044-0.188 \mathrm{x}$, $n=94, r^{2}=0.29, P<0.001$.

Single Leaf Gas Exchange. The data show that the relationship between gas exchange and leaf damage might be nonlinear. However, for reasons of simplicity a linear model was chosen to describe this relationship. We found a significant correlation between leaf brownness and single leaf net $\mathrm{CO}_{2}$ exchange; the browner the lower leaf surface, the lower the net $\mathrm{CO}_{2}$ exchange. This negative relationship was observed in both varieties but obviously stronger for leaves of Jonagold (Fig. 3). Similarly, there was a significant correlation between leaf brownness and leaf transpiration rate-the browner the lower leaf surface, the lower the transpiration rate. This correlation was again stronger for Jonagold than for Golden Delicious leaves (Fig. 3).

Changes in Leaf Tissue. The abaxial (lower) epidermis of uninfested leaves showed a smooth and nondisrupted surface. The stomata were closed and the guard cells turgescent (Fig. 4a). In contrast, the abaxial surface of infested leaves was uneven. The stomata were partially open and the guard cells had lost turgor (Fig. 4b). With the cryoscanning microscopy, we observed that the punctured wounds on the abaxial surface of infested leaves (Fig. $5 \mathrm{a}$ and $\mathrm{b}$ ) were caused by apple rust mite feeding. An apple rust mite was captured during feeding by cryofixation; the mite's stylet was just penetrating the leaf surface (Fig. $6 a$ ). The diameter of the apple rust mite stylet is $\approx 0.5$ $\mu \mathrm{m}$, similar to that of the feeding holes (Fig. 6b). The feeding holes were distributed in patches, suggesting that apple rust mites penetrate the same cell more than once.

Cross sections of infested (leaf damage level of 6-7) and noninfested leaves (Fig. $7 \mathrm{a}$ and b) demonstrated the effect of apple rust mite feeding on the abaxial epidermis and spongy parenchyma. The epidermal cells, including the guard cells, of damaged leaves were desiccated. Compared with an uninfested leaf, the epidermis layer of an infested leaf is only a thin remnant of epidermis and guard cells. Such damaged epidermis and guard cells are likely unable to fulfill their functions.

The photomicrographs showed also a visible difference in the spongy parenchyma of infested and non-
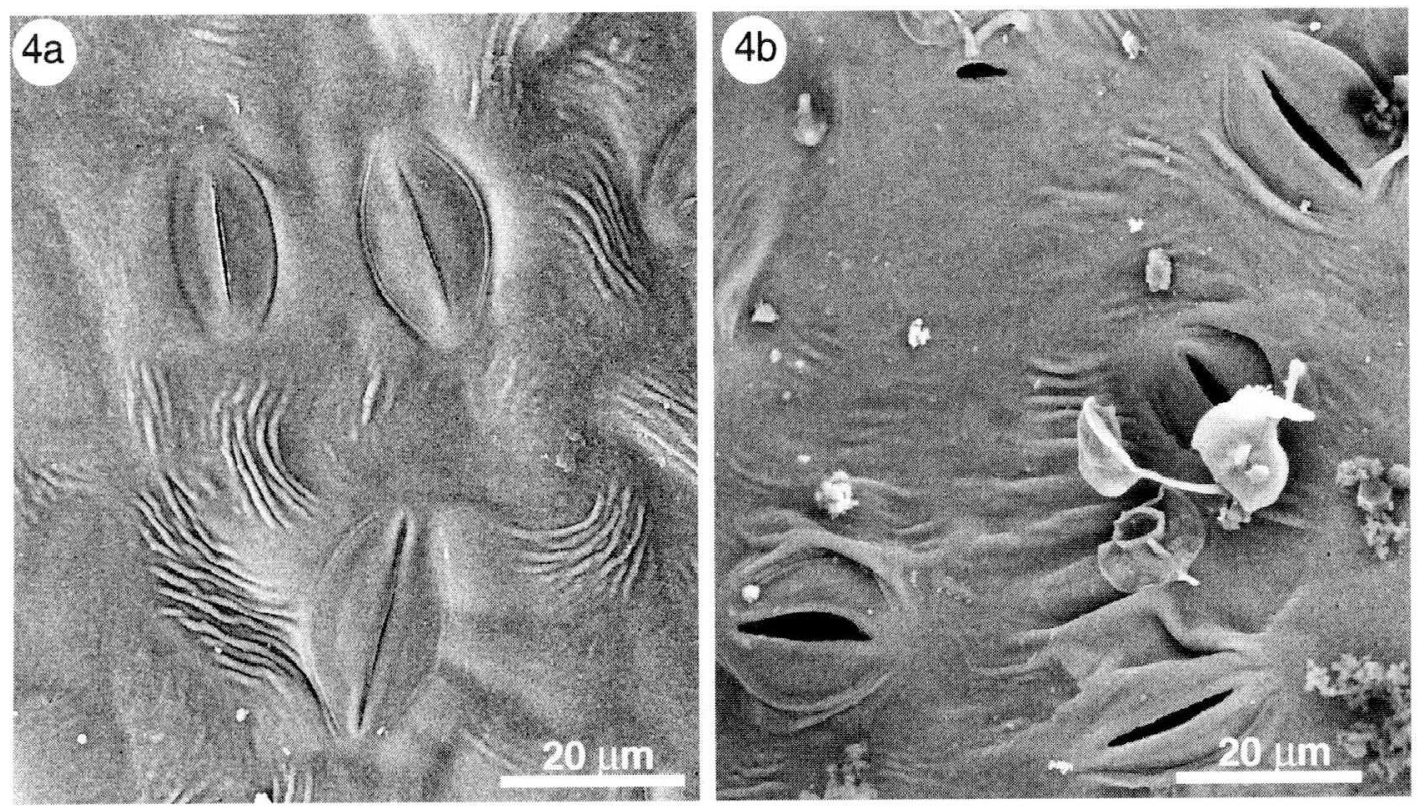

Fig. 4. Lower apple leaf surfaces. (a) Without apple rust mite infestation.(b) with infestation (b). 

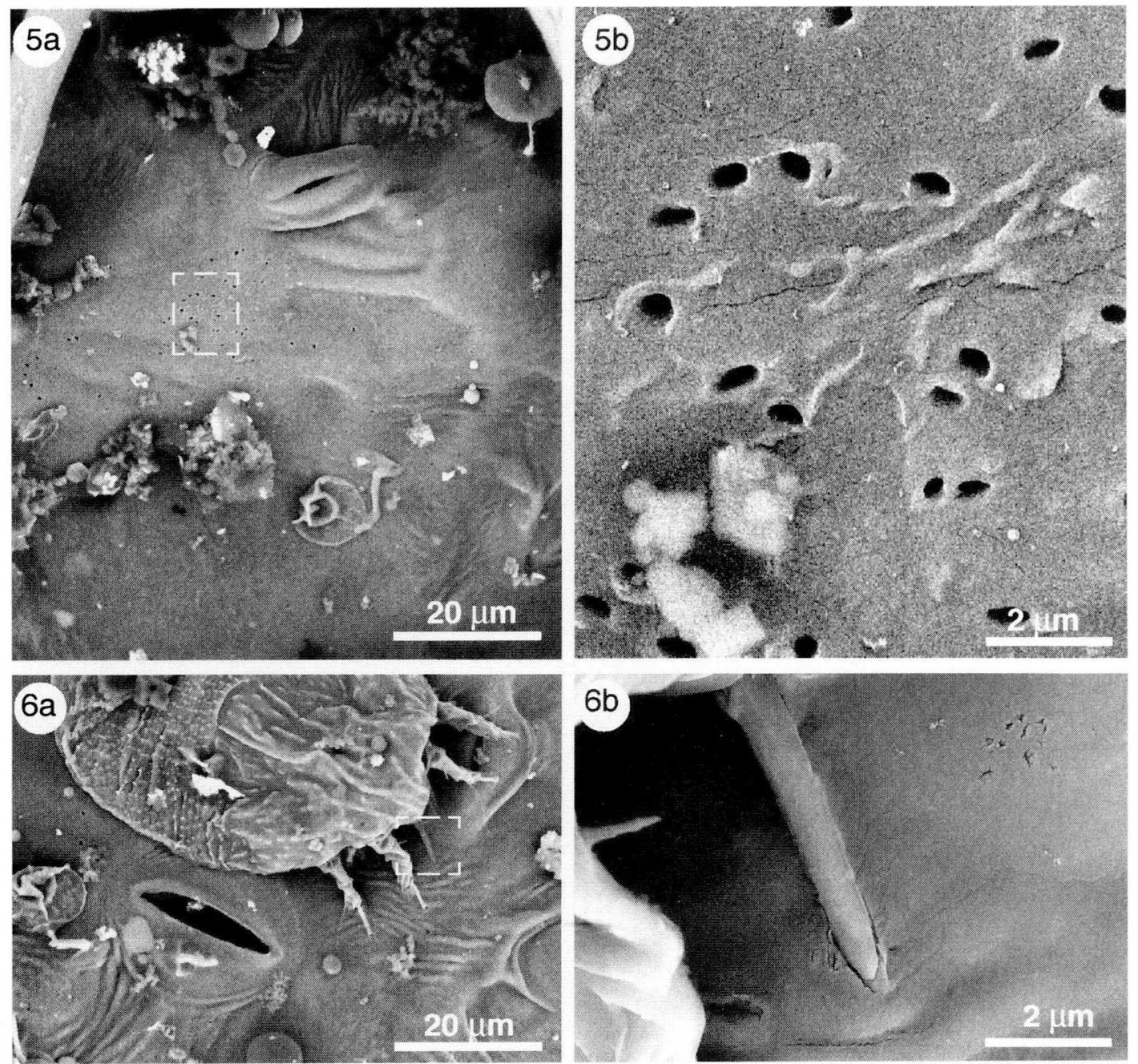

Figs. 5 and 6. (5) General view of an infested lower apple leaf surface. (a) Containing punctured wounds. (b) Detail of content of white rectangle in Fig. 5a showing puncture wounds. (6) (a) Apple rust mite on lower apple leaf surface penetrating epidermis with its stylet. (b) Detail of content of white rectangle in Fig. 6a showing stylet piercing leaf tissue.

infested leaves. Apple rust mite feeding caused the desiccation of the spongy parenchyma cells. There were no cell organelles visible and the cells lost turgor. Consequently, apple rust mites seem to have an influence on spongy parenchyma cells as well, even though they cannot reach deeper cell layers with their' stylets. Therefore, reduction of gas exchange might be caused by a malfunction of the stomata (direct effect) but also because of problems of gas exchange within the spongy parenchyma (indirect effect).

\section{Discussion}

Rust Mite Populations. In this study, the apple rust mite populations on untreated trees reached very high levels (some thousands) compared with other studies (some hundreds) (Solhoy 1991, Hengstberger 1993, Easterbrook 1996) and with common populations in commercial apple orchards (Herbert 1974; Gottwald and Krüger 1996). However, the pattern of development of apple rust mite populations on the experimental trees in 1996 is typical for eriophyoids. Apple rust mites may build up populations very rapidly because of a short generation time and a high fecundity (Easterbrook 1979, 1984; Schliesske 1985). The population declined rapidly after the completion of shoot growth; a phenomenon that has already been reported (Hengstberger 1993).

Browning of Leaves. High growth rates, mobility of apple rust mites within plants, and drift through the air (Schliesske 1989) may cause rapid population changes on a single leaf. Therefore, the mite population present on a leaf at any one moment gives only an imprecise assessment of the effective impact history and the influence on ecophysiological processes of the investigated leaf. There are 2 possibilities to integrate the historical impact of mite feeding on a leaf. One is to calculate the cumulative mite days by using several 

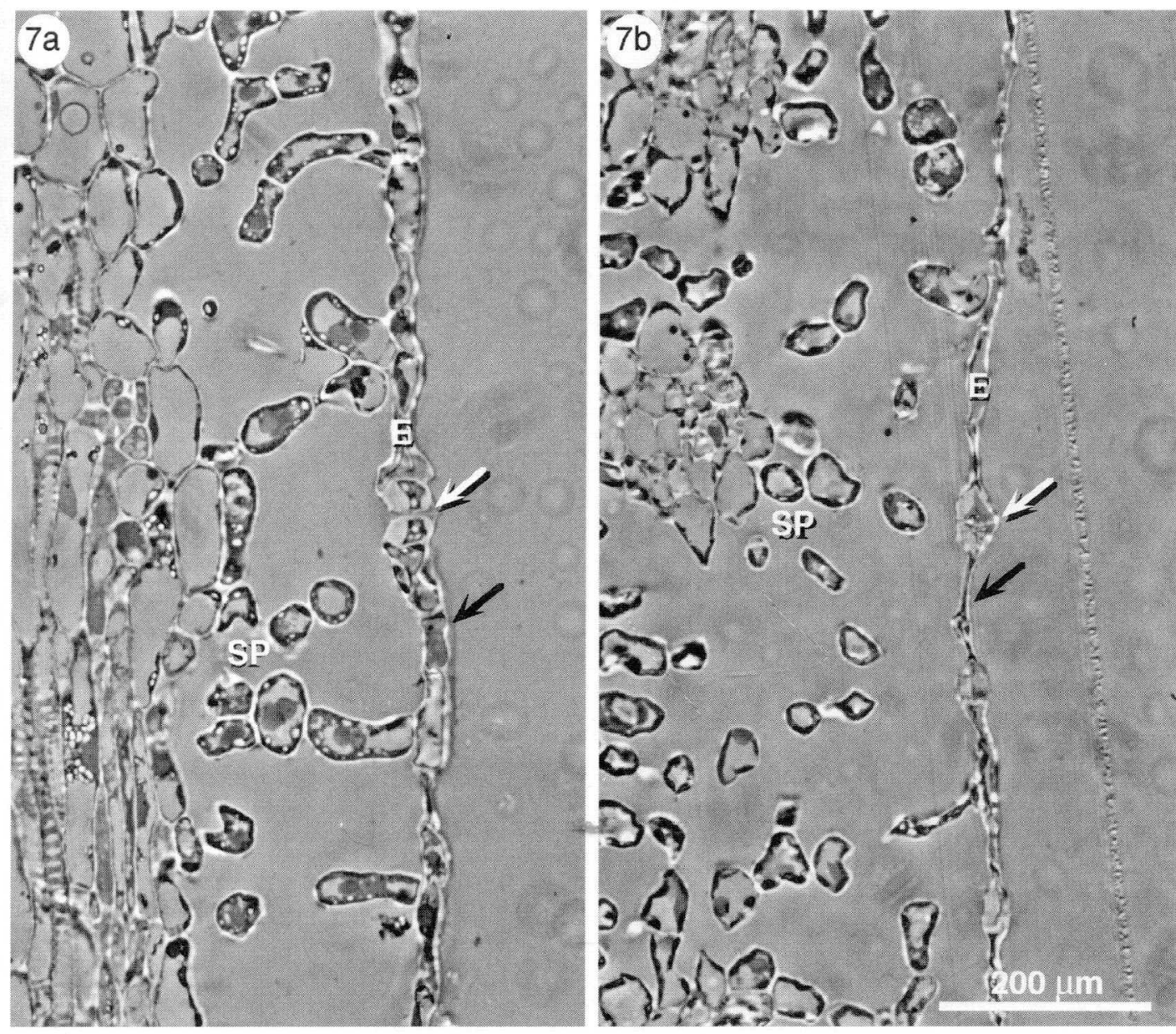

Fig. 7. Cross sections of a noninfested (a) and an infested apple leaf (b). E, lower epidermis; SP, spongy parenchyma, In contrast to noninfested leaves, the epidermis (black arrows) with stomata (white arrows) of infested leaves is completely desiccated. Symptoms of desiccation in the spongy parenchyma of infested leaves are visible.

counts of mite densities on the same leaf. Another possibility is to measure once the cumulative leaf damage directly. Unfortunately, the mite counting method used in this study did not allow us to calculate the cumulative mite days on the single leaf level because a new different leaf was used for each set of measurements. However, our results confirmed that apple rust mite feeding results in irreversible browning of the leaf (Figs. 1 and 2). Hence, the brownness of infested leaves is a measure of cumulative leaf damage and it was used as a very rapid method to assess the impact of apple rust mite feeding on leaf performance.

Gas Exchange Associated with Changes in Leaf Tissue. Studies with tetranychid mites and greenhousegrown apple have demonstrated that gas exchange parameters are reduced by mite feeding (Hall and Ferree 1975, Campbell et al. 1990a, Mobley and Marini 1990). There are studies that show similar results for European red mite, Panonychtus ulmi (Koch), and field-grown apple trees (Francesconi et al. 1996, Lakso et al. 1996). Spider mites pierce the leaf epidermis with needlelike mouthparts and feed primarily on meso- phyll and palisade layers of leaf (Avery and Briggs 1968, Tanigoshi and Davis 1978, Campbell et al. 1990b). Thus, photosynthesis is influenced directly. Because rust mites have shorter stylet lengths, they are not capable of feeding on the photosynthetically active mesophyll and palisade layers (Jeppson et al. 1975, Easterbrook and Fuller 1986, Royalty and Peering 1988). Another important difference between spider mites and rust mites is the potential density per leaf. Populations of rust mites may reach levels several times higher than those reached by spider mite populations. Therefore, the amount and distribution of penetration damage is expected to be different.

Easterbrook and Palmer (1996) investigated the relationship between early-season leaf feeding by apple rust mites and photosynthesis of field-grown apple. They found no effect of apple rust mite feeding on photosynthesis. However, the apple rust mite density ( $<100$ apple rust mites per leaf) was probably too low to cause any significant effect on photosynthesis. Royalty and Peering (1989) and Andersen and Mizell (1987) investigated the effect of other eriophyoids on 
gas exchange rate on tomato and peach and postulated reductions in gas exchange as high as 50 and $44 \%$, respectively.

In this study, very strong relationships were found between gas exchange rates of apple leaves and brownness of leaves caused by apple rust mite feeding (Fig. 3). The gas exchange rate of heavily infested leaves was reduced up to $65 \%$. The reduction of net $\mathrm{CO}_{2}$ exchange rate caused by apple rust mite feeding recorded by the described method might even be underestimated. For measurements, leaves were spread out in the cuvette and were fully expanded and exposed to the light. However, in nature, infested leaves are rolled up longitudinally, and therefore intercept less light than healthy leaves.

Apple rust mites produce multiple punctured wounds by the penetration of stylets into epidermis cells (Fig. $6 \mathrm{a}$ and b). Similar punctured wounds were found for Aceria cladophthirus (Nalepa) on Solanum dulcamare L. (Westphal and Manson 1996) and for citrus rust mite on citrus (McCoy and Albrigo 1975; Achor at al. 1991). The penetration and partial evacuation of epidermal cells by apple rust mites causes desiccation of the epidermis. Probably, undamaged cells (e.g., guard cells) may be affected indirectly by reduction in water or nutrient transport. This damage to the epidermis caused by apple rust mites is similar to that caused by Aculops lycopersici (Massee) (another free-living gall mite) feeding on tomato (Royalty and Peering 1988). The desiccation of the epidermis leads to malfunction of the stomata. Royalty and Peering (1988) and Andersen and Mizell (1987) observed a similar mechanism in tomato and peach leaves, respectively. They suggested that epidermal feeding by tomato russet mites and peach silver mites may permanently impair stomatal functions. In the apple rust mite-apple system, epidermis damage is particularly dramatic because apple rust mites feed on the abaxial leaf surface where the stomata are located. REM-pictures of infested leaves show some damaged stomata that are open and some that are closed (Fig. $4 \mathrm{a}$ and $\mathrm{b}$ ). Consequently, transpiration and net $\mathrm{CO}_{2}$ exchange might be reduced but it would be difficult to quantify the extent of reduction.

Cross sections of heavily infested apple leaves show that spongy parenchyma cells are desiccated. Cells lost turgor and cell organelles were destroyed (Fig. 7 and b). A similar effect was observed on citrus, where feeding by the citrus rust mite caused mesophyll collapse and defoliation (McCoy 1976). We also observed that heavily infested leaves dry up on the tree, although water supply was not limited. Hence, we infer there is resistance to water transport within the leaf. The damaged spongy parenchyma might cause this resistance. It is also possible that there is resistance to water transport in the midrib and that the damage of the spongy parenchyma is a consequence of water deficiency.

Apple rust mites may influence photosynthetic activity indirectly without feeding on the mesophyll or palisade tissue. In addition to the mechanical damage of the epidermis, apple rust mites or the plant itself might trigger a defence mechanism against apple rust mites, water loss, or secondary infections (fungus, herbivores). Stout et al. (1994) investigated induced enzyme activity by $A$. lycopersici on tomato and demonstrated that tomato responded to rust mite feeding with elevated activity of peroxidase and lipoxygenase. Another explanation for the change in spongy parenchyma is the collapse of the internal water and ion transport caused by the damaged epidermis. Saliva of apple rust mites may be another explanation for cell damage in the spongy parenchyma. Based on morphological examinations of tomato leaves, Royalty and Peering (1988) excluded the involvement of phytotoxins in the A. lycopersici-tomato interactions. Yang et al. (1995b) speculated that citrus rust mites inject digestive enzymes into cells while feeding. Westphal and Manson (1996) demonstrated with histochemical methods that chitin fragments or chitosan are introduced by the rust mite Thamnacus solani (Boczek \& Michalska) into the epidermal cells of Solanum dulcamare $\mathbf{L}$.

Although the damage mechanisms and their triggers (e.g., mechanical damage or saliva) are not fully understood, our study has demonstrated that on heavily infested apple trees, apple rust mite feeding causes epidermial and spongy parenchyma damage and reduces gas exchange.

\section{Acknowledgments}

We thank Heinrich Höhn for many helpful discussions and Hans Ueli Höpli for the photographs of the brightfield microscopy. We further acknowledge the help of Alfred Husistein and his field crew. Mirjam Probst and Francesca Ballmeli assisted the field work in 1995 and 1996. The study was supported by the Swiss National Science Foundation with Grant No. 31-40340.94.

\section{References Cited}

Achor, D. S., L. G. Albrigo, and C. W. McCoy. 1991. Developmental anatomy of lesions on 'Sunburst' mandarin leaves initiated by citrus rust mite feeding. J. Am. Soc. Hortic. Sci. 116: 663-668.

Andersen, P. C., and R. F. Mizell III. 1987. Impact of the peach silver mite, Aculus cornutus (Acari: Eriophyiidae), on leaf gas exchange of 'Flordaking' and 'June Gold' peach trees. Environ. Entomol. 16: 660-663.

Avery, D. J., and J. B. Briggs. 1968. Damage to leaves caused by fruit tree red spider mite, Panonychus ulmi (Koch). J. Hortic. Sci. 43: 463-473.

Campbell, R. J., K. N. Mobley, and R. P. Marini. 1990a Growing conditions influence mite damage on apple and peach leaves. HortScience 25: 445-448.

Campbell, R. J., R. L. Grayson, and R. P. Marini. 1990b. Surface and ultrastructural feeding injury to strawberry leaves by the twospotted spider mite. HortScience 25 : 948-951.

Easterbrook, M. A. 1979. The life-history of the eriophyoid mite Aculus schlechtendali on apple in South-east England. Ann. Appl. Biol. 91: 287-296.

1984. The biology and control of the rust mites Aculus schlechtendali and Epitrimerus piri on apple and pear in England, pp. 797-803. In D. A. Griffiths and C. E. Bowman [eds.], Acarology VI. E. Horwood, Chichester. 
1996. Damage and control of eriophyoid mites in apple and pear, pp 527-541. In E. E. Lindquist, M. W. Sabelis and J. Bruin [eds.], World crop pests, eriophyoid mites-their biology, natural enemies and control, vol. 6. Elsevier, Amsterdam.

Easterbrook, M. A., and M. M. Fuller. 1986. Russeting of apples caused by apple rust mite Aculus schlechtendali (Acarina: Eriophyiidae). Ann. Appl. Biol. 109: 1-9.

Easterbrook, M. A., and J. W. Palmer. 1996. The relationship between early-season leaf feeding by apple rust mite, Aculus schlechtendali ( $\mathrm{Nal}$.), and fruit set and photosynthesis of apple. J. Hortic. Sci. 71: 939-944.

Elstner, E. F. 1990. Der Sauerstoff: Biochemie, Biologie, Medizin, pp. 485-489. BI-Wiss.-Verl, Mannheim.

Francesconi, A.H.D., A. N. Lakso, J. P. Nyrop, J. Barnard, and S. Denning, 1996. Carbon balance as a physiological basis for the interactions of European red mite and crop load on 'Starkrimson Delicious' apple trees. J. Am, Soc. Hortic. Sci. 121: 959-966.

Gottwald, R., and F. Krüger. 1996. Methodische Untersuchungen zur Ermittlung des Befalls durch die Obstbaumspinnmilbe, Panonychus ulmi (Koch), und die Apfelrostmilbe, Aculus schlechtendali (Nalepa), an Blättern unterschiedlicher Altersstufen. Nachrichtenbl. Deut. Pflanzenschutzd. 48(4): 69-72.

Hall, F. R., and D. C. Ferree. 1975. Influence of twospotted spider mite populations on photosynthesis of apple leaves. J. Econ. Entomol. 68: 517-520.

Hengstberger, K. 1993. Beiträge zur Biologie der Apfelrostmilbe Aculus schlechtendali (Nalepa) im östereichischen Obstbau. Ph.D. dissertation, University of Wien, Austria.

Herbert, H. J. 1974. Notes on the biology of the apple rust mite, Aculus schlechtendali (Prostigmata: Eriophyiidae), and its density on several cultivars of apple in Nova Scotia. Can. Entomol. 106: 1035-1038.

Höhn, H., and H. U. Höpli. 1990. Die Apfelrostmilbe - oft überschätzt, aber kaum prognostizierbar! Schweiz. Z Obst Weinbau 126: 259-266.

Jeppson, L. R., H. H. Keifer, and E. W. Baker. 1975. Mites injurious to economic plants. University of California Press, Berkeley.

Lakso, A. N., G. B. Mattii, J. P. Nyrop, and S. S. Denning. 1996. Influence of European red mite on leaf and wholecanopy carbon dioxide exchange, yield, fruit size, quality, and return cropping in 'Starkrimson Delicious' apple trees. J. Am. Soc. Hortic. Sci. 121 (5): 954-958.

McCoy, C. W. 1976. Leaf injury and defoliation caused by the citrus rust mite, Phyllocoptruta oleivora. Fla. Entomol 59: 403-410.

McCoy, C. W., and L. G. Albrigo. 1975. Feeding behaviour and nature of injury to the orange caused by citrus rust mite, Phyllocoptruta oleivora (Prostigmata: Eriophyiidae). Ann. Entomol. Soc. Am. 68: 289-297.

Mobley, K. N., and R. P. Marini. 1990. Gas exchange characteristics of apple and peach leaves influenced by European red mite and twospotted spider mite. J. Am. Soc Hortic. Sci. 115: 757-761.

Royalty, R. N., and T. M. Peering. 1988. Morphological analysis of damage to tomato russet mite (Acari: Eriophyiidae). J. Econ. Entomol. 81: 816-820.
1989. Reduction in photosynthesis of tomato leaflets caused by tomato russet mite (Acari: Eriophyiidae). Environ. Entomol. 18: 256-260.

Rutz, Ch., U. Hugentobler, H. Chi, J. U. Baumgärtner, and J. J. Oertli. 1990. Energy flow in apple plant-aphid (Aphis pomi De Geer) (Homoptera: Aphididae) ecosystem, with respect to nitrogen fertilization, pp. 625-631. In M. L. Van Beusichem [ed.], Plant nutrition-physiology and applications. Kluwer, New York.

Schliesske, J. 1985. Zur Biologie und zum Schadauftreten der Gallmilben Aculus schlechtendali (Nalepa) (Acari: Eriophyiidae) an Malus spp. Erwerbsobstbau 27: 195-197.

Schliesske, J. 1989. Ausbreitungsmadi von Gallmilben (Acari: Eriophyiidae). Mitt. Dtsch. Ges. Allg. Angew. Entomol. 7: 166-168.

Solhoy, T., E. Dybwad, K. Hesjedal, M. Hossain, and B. Hovland. 1991. Observations on Aculus schlechtendali (Nal.) (Acari: Eriophyiidae) in apple orchards in western Norway, pp. 533-538. In F. Dusabek and V. Bukva [eds.], Modern acarology, vol. 1. Academia, Prague.

Stout, M. J., J. Workman, and S. S. Duffey. 1994. Differential induction of tomato foliar proteins by arthropod herbivores. J. Chem. Ecol. 10: 2575-2594

Tanigoshi, L. K., and R. W. Davis. 1978. An ultrastructural study of Tetranychus mcdanieli feeding injury to the leaves of 'Red Delicious' apple (Acari: Tetranychidae). Int. J. Acarol. 4(1): 47-56.

Walther, $P$., and M. Müller. 1997. Double layer coating for field emission cryo-scanning electron microscopy present state and applications. Scanning 19: 343-348.

Welter, S. C. 1989. Arthropod impact on plant gas exchange, vol. I. pp. 135-164. In E. A. Bernays [ed.], Insect-plant interactions. CRC, Boca Raton, FL.

Westphal, E., and D.C.M. Manson. 1996. Feeding effects on host plants: gall formation and other distortions, vol. $6, \mathrm{pp}$. 231-242. In E. E. Lindquist, M. W. Sabelis, and J. Bruin [eds.], World crop pests, eriophyoid mites-their biology, natural enemies and control. Elsevier, Amsterdam.

Yang, Y., J. C. Allen, J. L. Knapp, and P. A. Stansly. 1994 Citrus rust mite (Acari: Eriophyiidae) damage effects on 'Hamlin' orange fruit growth and drop. Environ. Entomol. 23: 224-247.

1995a. Frequency distribution of citrus rust mite (Acari: Eriophyiidae) damage on fruit in 'Hamlin' orange trees. Environ. Entomol. 24: 1018-1023.

1995b. Relationship between population density of citrus rust mite (Acari: Eriophyiidae) and damage to 'Hamlin' orange fruit. Environ. Entomol. 24: 1024-1031.

Zalom, F. G., J. Kitzmiller, L. T. Wilson, and P. Gutierrez. 1986. Observation of tomato russet mite (Acari: Eriophyiidae) damage symptoms in relation to tomato plant development. J. Econ. Entomol. 79: 940-942.

Received for publication 7 January 1998; accepted 15 June 1998. 